\title{
Effect of Nozzle in High Pressure Humidification Systems of Water Evaporator
}

\author{
https://doi.org/10.3991/ijoe.v17i09.23887 \\ Vasyl Savchenko ${ }^{1}(\underset{\varpi}{ })$, Andrii Kravtsov², Serhii Minenko ${ }^{1}$, Volodymyr Kulykivskiy ${ }^{1}$, \\ Liudmyla Savchenko ${ }^{1}$ \\ ${ }^{1}$ Polissya National University, Zhytomyr, Ukraine \\ ${ }^{2}$ Kharkiv Petro Vasylenko National Technical University of Agriculture, Kharkiv, Ukraine \\ ztrololozeukr. net
}

\begin{abstract}
This paper describes the comparative analysis of nozzles efficiency in high pressure water vapor systems based on different operating time and quality of their work. These nozzles described the size of water droplet and convert it into moisture. Which help to manage the room temperature. Literature survey revealed an insufficient number of studies in the field of stability and reliability of nozzles. As, it is the strong candidate in performance of the humidifiers. The purpose of this work is to test and complement the results of the received theoretical provisions, the establishment of values of the rational time of operation of the nozzles. The action plan includes laboratory and industrial tests. The main parameters focused here, were the contamination of the nozzle filters at their different operating times, the performance of the nozzles with variable operating time, as well as the nozzle spray torch, and most importantly the quality of the injector. The cone shaped nozzle was used to test the effectiveness of the spray by assuming that the water torch is coming from the nozzle. Weight method was used to estimate the degree of contamination in filters. In this study, it was found that nozzle filters increase their weight by more than $45 \%$ when operating for more than 1,500 hours, which reduces their throughput and, as a result, reduces the performance of the injectors by more than $20 \%$. In this case, the spray torch does not cover the required area, which leads to deterioration of the system and the appearance of micro-drafts. Experimental studies have shown the need for maintenance of injectors within 12001300 hours of operation. Moreover, the increase in contamination of the filter effects the performance of the filter. And the stability of the diameter of the torque torch explained by critical clamping of the nozzle filter.
\end{abstract}

Keywords—nozzle, evaporation, filter, stability, productivity

\section{$1 \quad$ Introduction}

Mostly, air conditioners are extensively used to cool rooms and buildings. In these mechanically assertive devices maintain temperature by degenerating the environment inturn increasing the energy consumption. To lessen the environmental degradation, the requirement for energy-efficacious and environmentalfriendly systems for cooling 
in summer becomes extremely important $[1,2]$. Evaporative cooling, a typical passive cooling technique, could meet the energy demand and global climatic issues. Evaporation cooling underlies one of the first-mentioned man's cooling systems where air cooling occurs due to natural water evaporation. To combat high temperatures in the warm period of the year, evaporation cooling is used, and in the cold period of the year nozzle is used to moisten air [3]. It has been found that at the end of the stream from the openings of blocked arches, effective crushing occurs, both due to the collision of the counter flows, and because of the arc of the self-oscillatory process [4-6].

High pressure humidification systems can supply cooling as well as humidification for both big and small areas precisely. As these systems use heat from air for evaporation, which make them cost effective. The efficiency and life of this system can also be increased by little work on nozzle and filter used to moisten air. Numerous experimental studies have shown that different shapes of fluid jets used in humidifier, falling into in the gas medium has different effect on quality. Under certain conditions, the fluid pulsation is amplified along the jet and leads to a decay of it on a drop. The character of the pulsating movement depends on the form of nozzle, which follows a jet, scale of initial turbulence of liquid in a jet, physical properties of liquid and gas and their relative velocity [2][7].

\section{Literature Review and Problem Statement}

At the very initial stage of research on effect of droplet size, many calculation and models were introduced to study the effect on humidifier efficiency [8, 9]. That relates the drop size calculation with transfer of heat and droplet size. The widespread application of sawing is due to the fact that during these processes, reducing the size of droplets, increases the heat transfer coefficient, and therefore reduces the processing [10].Niroomend et al. [11] reported the mathematical modelling of effect of droplet size on humidification and cooling. They concluded that the size of drop coming from nozzle increase the moist in air or increase the water production. Numerous works on the study of the working state of nozzles do not describe the boundary states, in which the nozzle does not perform the functions laid on it. Working state of nozzles depends on many factors that characterize the conditions of their work (the quality of water supplied to the nozzles, the time of operation of the nozzles, cyclicity of work, etc.) $[12,13]$.

Klausner et al. [14] has used a combination of a shell and tube heat exchanger in humidifier to give improved performance for each cycle. They also measure the usage of packed bed in direct contact humidification-dehumidification cycle. They investigated the heat evaporation and mass transfer for the designed system and made comparative analysis with the experimental results [15]. The theoretical model for the aforementioned relation between mass transfer and heat exchange system is also developed by Alnaimat et al. [16]. Eslamimanesh and Hatamipour [17] has reported a direct contact humidification-dehumidification process. Zamen et al. [18]described a novel humidification-dehumidification system based upon direct contact for the production of freshwater in greenhouse. They designed a greenhouse integrated system 
that yield the required amount of energy using solar absorber tubes. These tubes are placed in a sealed area under the ceiling of the greenhouse $[19,20]$. But there is an insufficient number of studies in the field of stability and reliability of nozzles.

In accordance with theproblems, the purpose of the article is to conduct experimental research with nozzles that have different developments and adoption of recommendations for maintenance of nozzles or replacement.

\section{$3 \quad$ Amis and Objective}

The purpose of experimental research is to test and complement the results of the received theoretical provisions, the establishment of values of the rational time of operation of the nozzles, in which the permissible requirements, as well as checking the quality of work of the elements of the nozzles. The action plan includes laboratory and industrial tests. In accordance with the set goal in laboratory conditions it is assumed:

1. Study of contamination of filters of nozzles with their different work.

2. Study of performance of nozzles with change of work.

3. Study of a torch of spray nozzles as the main parameter of the operation of the injector.

The main indicators that determine the quality of the injectors are its productivity and torch of the separation, the decrease of which to values below $20 \%$ of the nominal determines the non-customary state of the nozzle. In addition, the failure of the nozzle should be considered: the addition of water through a nozzle due to the failure of the filter and failure of the shut-off valve. To determine the operation of the nozzle, we determine its productivity, that is, the amount of water passing through the nozzle for a certain time.

\section{$4 \quad$ Research Methodology}

To conduct laboratory tests, the object of the study is a mock-up sample of the fogformation system. The schematic presentation of system is shown in Figure 1(a), which consists of the following basic nodes: a pumping station consisting of a plunger pump of high pressure, a pump drive, an electric motor; pressure gauge; high pressure pipes with fittings, special purpose; nozzles; adjusting crane. Figure 1(b) represent the optical photograph of the system used during the experiment. 


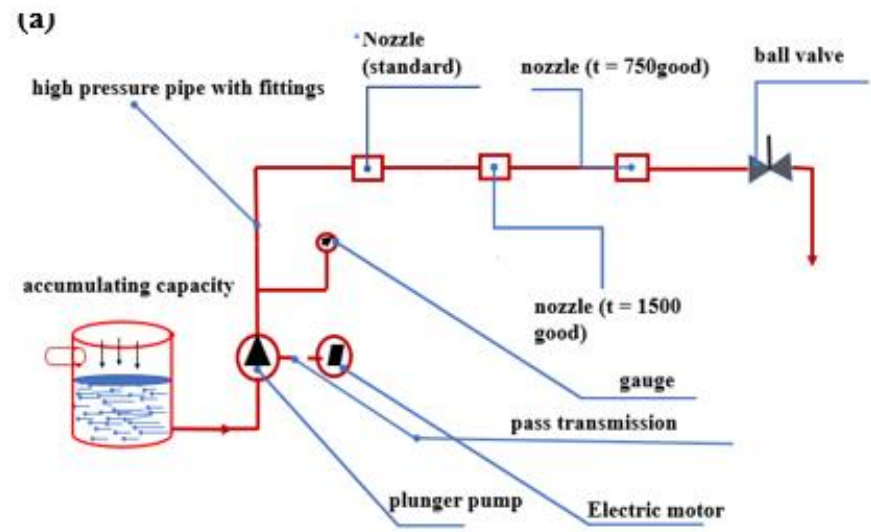

(b)

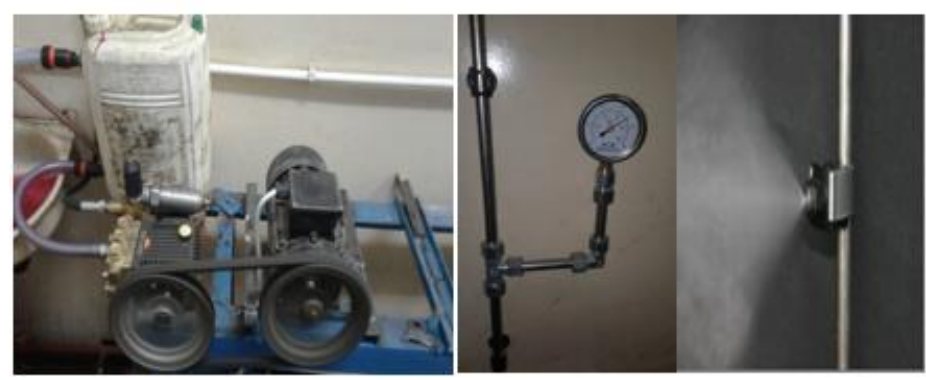

Fig. 1. The header image of Laboratory installation for testing of fog-formation systems: a circuit, $\mathrm{b}$ - general view

The principle of operation of the experimental installation is as follows: Water from the central path under pressure 2-3 bar is fed to a battery tank, where there is a mixing of water with a dye.The paint WWM (C10 / 11set4-2) was taken as a dye, which is completely soluble in water. After that, the mixture is fed into the plunger pump, which creates a pressure gauge at the output of the pressure gauge. And a mixture of high-pressure pipes moves to nozzles. The general view of the nozzle for the formation of fog is shown in figure 2(a) and its schematic presentation is shown in figure 2(b). 
(a)

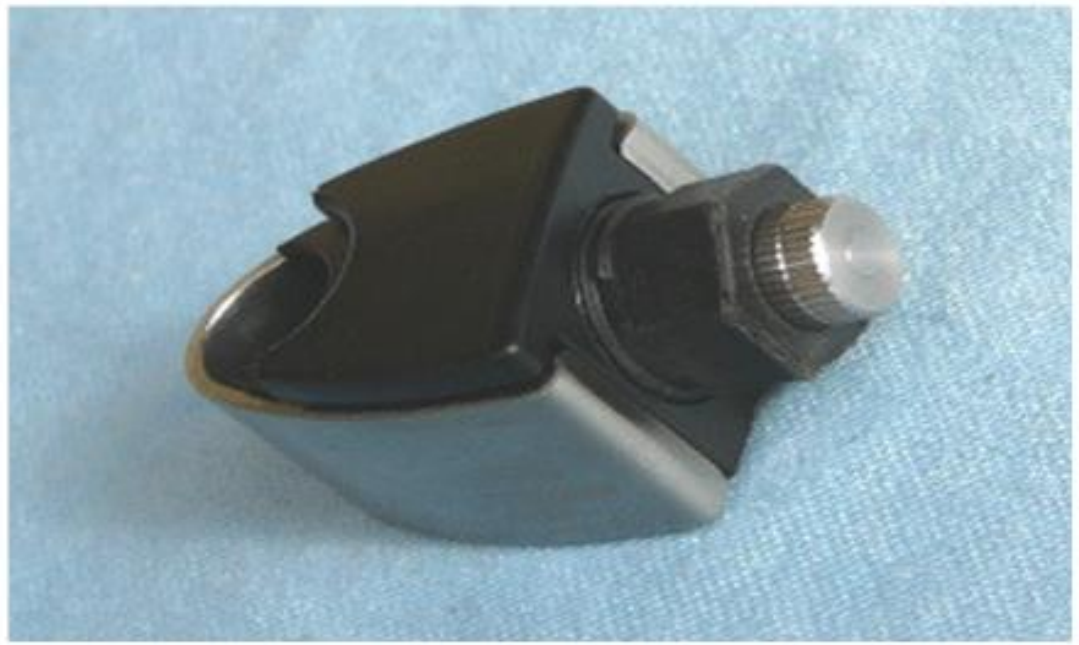

(b)

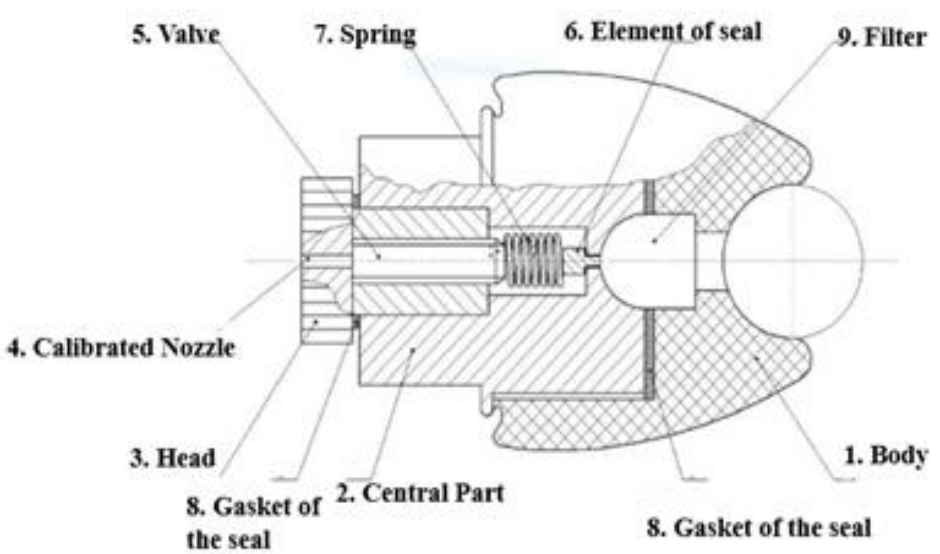

Fig. 2. .Nozzle for the formation of dispersed fog in the room of greenhouses: a) a general view; b) schematic representation

\section{$5 \quad$ Results and Discussion}

Figure 3 shows the schematic optical photograph of the ferry filter, which represent the feeding of aqueous solution from pipeline to filter where the separation of the impurities is occurred. In this study, we consider the nozzle as a technical system bases on its several mechanisms that provide its normal functioning. Through the central portion of 2 injection nozzles in 60-120 bar solution acts on safety from the flow of nozzle sealing element 6 of the valve 5, as shown in the figure 4. Liquid, having fallen into the internal volume of the central part, under pressure is fed to a calibrated nozzle- 4 head by droppingpressure at the output of the nozzle- 3 , simultaneously, the liquid is dispersed into small particles of fog. At this point, the torch of 
the formed fog can reach up to $3 \mathrm{~m}$ distances from the nozzle. Since the productivity of the plunger pump increased to $450 \mathrm{~h}^{-1}$. In the same case, the productivity of one nozzle is $4.1 \mathrm{~h}^{-1}$ (on the way mounted 3 nozzles). After that, we put a ball of nozzle- 8 $(t=750$ good $)$ crane at the end of path, as a throttle.To align the productivity of the pump with the productivity of 3 nozzles. A crane, a mixture of drainage hose is drawn into drainage.

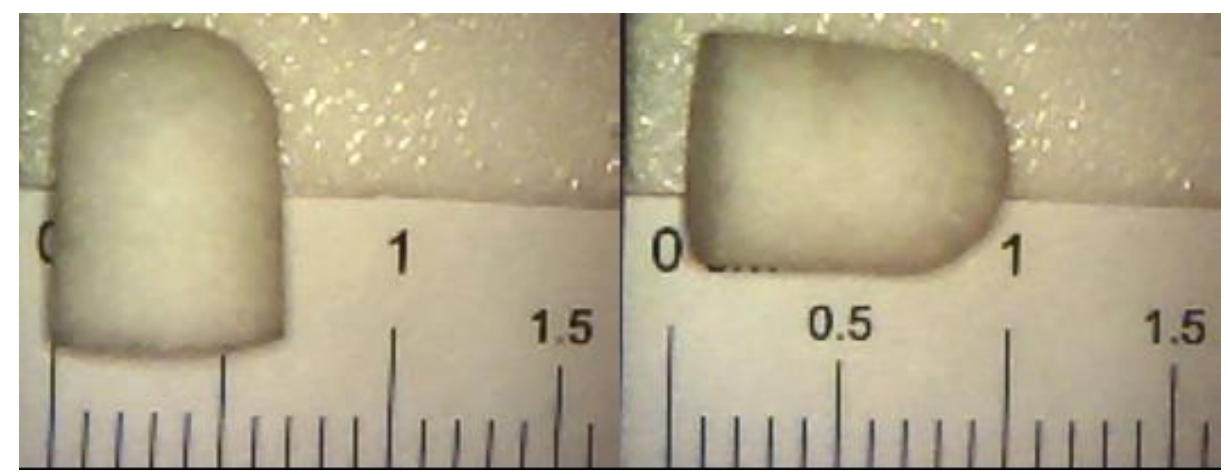

Fig. 3. Optical Micrograph of Ferry filter

To determine the contamination of the filter, photographing of filters was done for both new and different developments in 4 sections (Figure 4) and a weight method. For photography, a Sigeta CAM-03 microscope was used, which allowed to increase the results of photography 50 times as compared to conventional microscope used. The results of photo-fixation of filters with different developments were investigated for the presence of white (non-contaminated) parts.

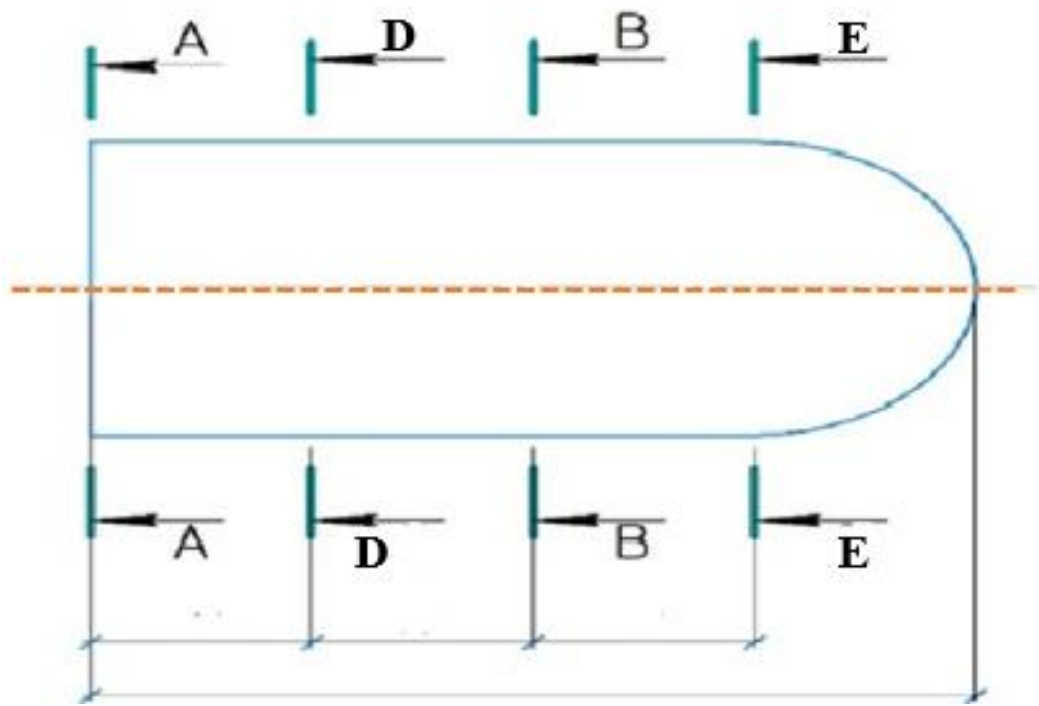

Fig. 4. Schematic representation of filter photography 
The results of photography are given in Table 1 .

Table 1. Exampletable The results of photographing filters with increasing them 50 times

\begin{tabular}{|c|c|c|c|c|}
\hline $\begin{array}{l}\text { No. of Filler } \\
\text { and operat- } \\
\text { ing time }\end{array}$ & $\begin{array}{c}\text { picture } \\
1\end{array}$ & $\begin{array}{c}\text { picture } \\
2\end{array}$ & $\underset{3}{\text { picture }}$ & $\begin{array}{c}\text { picture } \\
4\end{array}$ \\
\hline 1 & 2 & 3 & 4 & 5 \\
\hline \multicolumn{5}{|l|}{1 (New) } \\
\hline \multicolumn{5}{|l|}{ 2(750 hours) } \\
\hline & 2 & 3 & 4 & 5 \\
\hline \multicolumn{5}{|l|}{$\begin{array}{l}3(1000 \\
\text { hours })\end{array}$} \\
\hline \multicolumn{5}{|l|}{$\begin{array}{l}4(1500 \\
\text { hours })\end{array}$} \\
\hline
\end{tabular}

Subsequently, the degree of contamination of filter was investigated by a weight method. The results are given in Table 2.To implement this method, electronic digital scale-500 (500 g \pm 0.1$)$ were used. In this case, filters weighed with a moisture content of $10 \%$. The performance of the nozzle was determined on a laboratory installation with the help of equipment shown in figure 5: consist of three glass flasks, one measuring cylinder (GOST 1770-74) and a stopwatch (DSTU7230: 2011).

Table 2. Results of weighing filters

\begin{tabular}{|l|c|c|}
\hline \multicolumn{1}{|c|}{$\begin{array}{c}\text { No. of filter } \\
\text { (work out) }\end{array}$} & $\begin{array}{c}\text { Weight } \\
\text { (g) }\end{array}$ & Contamination, \% \\
\hline 1 (New) & 0.11 & 0 \\
\hline $2(750$ hours) & 0.14 & 87.5 \\
\hline $3(1000$ hours $)$ & 0.14 & 87.5 \\
\hline $4(1500$ hours $)$ & 0.15 & 93.75 \\
\hline
\end{tabular}

During the experiment, per minute flow rate through the nozzle was determined. The process was conducted three times on a new nozzle, repeatability. The nozzles 
have working time of 750 hours and 1500 hours, with 3 single reposited. The results obtained from this part of experiment are given in Table 3. Time for system operation in determining the productivity was 1 minute. In this case, the amount of water in a glass flask was consider as the per minute flow rate of the test nozzle (QXV).

Table 3. Results of performance of nozzles

\begin{tabular}{|l|c|c|c|c|}
\hline $\begin{array}{c}\text { Work out } \\
\text { nozzles, (h) }\end{array}$ & $\begin{array}{c}\text { 1 Zipir, } \\
\text { ml (1/ hour) }\end{array}$ & $\begin{array}{c}\text { 2 Zipr, } \\
\text { ml ( / / hour) }\end{array}$ & $\begin{array}{c}\text { 3 Zipr, } \\
\text { ml ( / / hour })\end{array}$ & $\begin{array}{c}\text { Average } \\
\text { value }\end{array}$ \\
\hline Novel & $68(4,08)$ & $70(4,2)$ & $67,5(4,05)$ & $68,5(4,11)$ \\
\hline 750 hours & $65(3,9)$ & $67(4,02)$ & $66(3,96)$ & $66(3,95)$ \\
\hline 1000 hours & $61,2(3,67)$ & $59,5(3,57)$ & $60,5(3,63)$ & $60,8(3,65)$ \\
\hline 1500 hours & $52(3,12)$ & $53(3,18)$ & $51(3,06)$ & $52(3,12)$ \\
\hline
\end{tabular}

For the transition from the minute flow of water in $1 / \mathrm{h}$ used the formula:

$$
Q=A * v
$$

Where $A$ is the area of nozzle and $v$ is the velocity of water $(\mathrm{m} / \mathrm{s} 2)$. The results obtained were compared with the nominal data of the manufacturer.

The effectiveness of the spray was evaluated by assuming that the water torch is coming from the nozzle is of cone shaped. After the injector, the torch saw also has a cone-shaped fire, but with a smaller diameter from the bottom, which leads to a decrease in the diameter of the area covered and because of the appearance of turbulent flows and microprobes, which is harmful to plants. To evaluate the shape and geometric size of the water cone, created by the nozzle by using the scheme shown in the Figure 5.

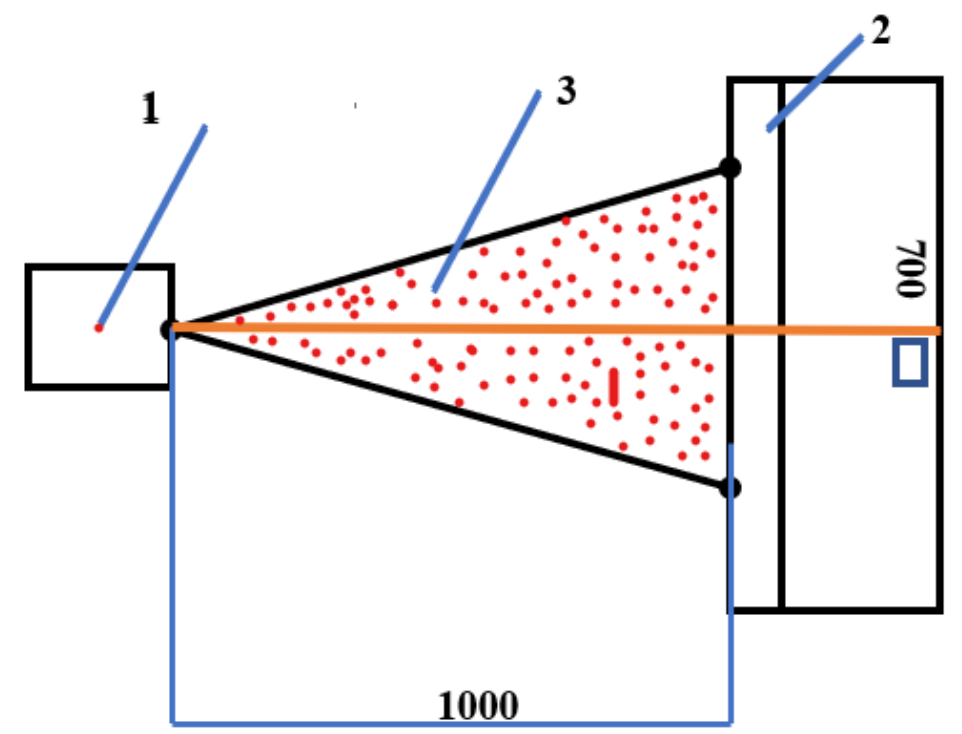

Fig. 5. Scheme of taking a torch print 
For a controlled image of the torch, water was painted in colour, with WWM paint (C10 / 11set4-2), which is soluble in water and does not affect the process of system. Dyed water was fed to a white canvas located at 1 meter within 3 minutes, for nozzles with different developments. Subsequently, graphic treatment was carried out, which allowed to determine the area of water in a horizontal plane for nozzles with different developments. One of the main criteria of the working state of nozzles, which affects the work of the entire system is the change in the productivity of the nozzles (see Table 4).

Table 4. Results of a torch study S

\begin{tabular}{|l|c|c|c|c|}
\hline $\begin{array}{c}\text { Work out } \\
\text { nozzles, (h) }\end{array}$ & $\begin{array}{c}\text { 1 Zipir, } \\
\text { ml (l / hour) }\end{array}$ & $\begin{array}{c}\text { 2 Zipr, } \\
\text { ml (l / hour) }\end{array}$ & $\begin{array}{c}\text { 3 Zipr, } \\
\text { ml (l / hour) }\end{array}$ & $\begin{array}{c}\text { Average } \\
\text { value }\end{array}$ \\
\hline Novel & $68(4,08)$ & $70(4,2)$ & $67,5(4,05)$ & $68,5(4,11)$ \\
\hline 750 hours & $65(3,9)$ & $67(4,02)$ & $66(3,96)$ & $66(3,95)$ \\
\hline 1000 hours & $61,2(3,67)$ & $59,5(3,57)$ & $60,5(3,63)$ & $60,8(3,65)$ \\
\hline 1500 hours & $52(3,12)$ & $53(3,18)$ & $51(3,06)$ & $52(3,12)$ \\
\hline
\end{tabular}

The manufacturer regulates the replacement of the filter element when reducing the performance of the nozzle by $20 \%$, that is, to a level of $3.36 \mathrm{~h}-1$. The results of laboratory studies are depicted in figure 6.

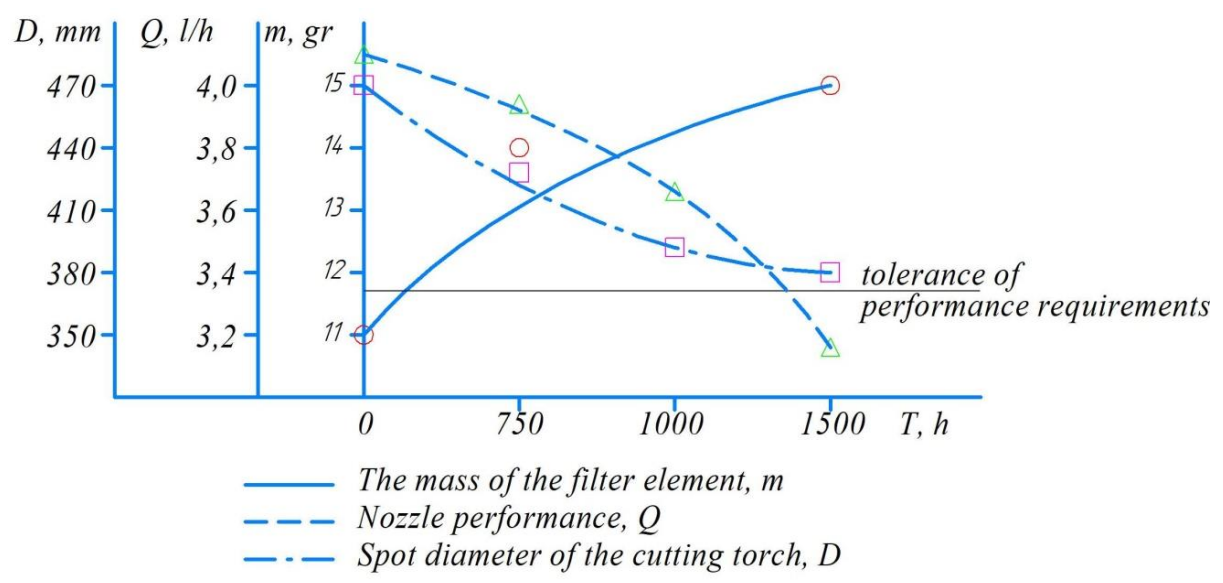

Fig. 6. Performance of the nozzles by changing the mass of the filter element, and the diameter of the fifth torch from the work of the nozzle

Which shows the Changing the mass of the filter element, performance of the nozzles and the diameter of the fifth torch from the work of the nozzle. From this graph, with the development of contamination of the filter growing, due to an increase in impurities on the filter elements of the nozzle and as a consequence of the performance of the nozzle falls. In this case, the diameter of the torque torch begins to stabilize, which is explained by critical clamping of the nozzle filter. 


\section{Conclusions}

The lab scale results of the operation of the system of water-visual humidification of high pressure showed that with an increase in the work of filters nozzles increase their weight by more than $45 \%$, which explains the presence of impurities in water, while reducing the productivity of nozzles by more than $20 \%$, which leads that poorquality the system's work. In this case, the torch of the scattering decreases, and consequently, the necessary area of the room is not covered with fine-dispersed water. The manufacturer of nozzles offers a replacement of filters when dropping performance by more than $20 \%$. In experimental studies, it is stained that the replacement of the filter element of nozzles is expedient to be carried out when the system is exposed within $1200-1300$ hours of operation.

\section{$7 \quad$ References}

[1] M. Mahesh, P. Thangavel, K. Bhuvaneshwaran, V. Boopathi Raja and S. Dinaesh Krishna, "Performance Evaluation of Portable Mist Humidifier", IOP Conference Series: Materials Science and Engineering, vol. 995, p. 012030, 2020, https://doi.org/10.1088/1757$\underline{899 x / 995 / 1 / 012030}$

[2] X. Huang, D. Zhang and X. Zhang, "Experimental research on spray cooling features of pressure nozzle in humidification chamber", Environmental Engineering and Management Journal, vol. 18, no. 11, pp. 2533-2541, 2019, https://doi.org/10.30638/eemj.2019.239

[3] Gregory, Kenneth J. The Earth's Land Surface: Landforms and Processes in Geomorphology. London: SAGE Publications Ltd, 2010. http://dx.doi.org/10.4135/ 9781446251621

[4] D. Zhang, Q. Du, Z. Zhang, X. Jiao, X. Song and J. Li, "Vapour pressure deficit control in relation to water transport and water productivity in greenhouse tomato production during summer", Scientific Reports, vol. 7, no. 1, 2017. https://doi.org/10.1038/srep43461

[5] A. Jaffrin, N. Bentounes, A. Joan and S. Makhlouf, "Landfill Biogas for heating Greenhouses and providing Carbon Dioxide Supplement for Plant Growth", Biosystems Engineering, vol. 86, no. 1, pp. 113-123, 2003, https://doi.org/10.1016/s1537-5110 (03)00110-7

[6] B. Jabir, N. Falih, and K. Rahmani, Accuracy and Efficiency Comparison of Object Detection Open-Source Models. International Journal of Online \& Biomedical Engineering, vol. 17, no. 5, pp 165-184, 2021, https://doi.org/10.3991/ijoe.v17i05.21833

[7] W. Xavier,G.Quilachamin, J.Evangelina,S.Cano, J.Herrera-Tapia, E. Javier and V. Zambrano., Analysis of A Two-Axis Solar Tracker System: Case Study. International Journal of Online \& Biomedical Engineering, vol. 17, no.5 2021, https://doi.org/10. 3991/ijoe.v17i05.21991

[8] P. Weisensee, Y. Wang, H. Qian, D. Schultz, W. King and N. Miljkovic, "Condensate droplet size distribution on lubricant-infused surfaces",International Journal of Heat and Mass Transfer, vol. 109, pp. 187-199, 2017, https://doi.org/10.1016/j.ijheatmasstransfer .2017.01.119.

[9] Y. Yang, G. Cui and C. Lan, "Developments in evaporative cooling and enhanced evaporative cooling - A review", Renewable and Sustainable Energy Reviews, vol. 113, p. 109230, 2019, https://doi.org/10.1016/j.rser.2019.06.037 
[10] A. González-Briones, P. Chamoso, H. Yoe and J. Corchado, "GreenVMAS: Virtual Organization Based Platform for Heating Greenhouses Using Waste Energy from Power Plants", Sensors, vol. 18, no. 3, p. 861, 2018, https://doi.org/10.3390/s18030861

[11] N. Niroomand, M. Zamen and M. Amidpour, "Theoretical investigation of using a direct contact dehumidifier in humidification-dehumidification desalination unit based on an open-air cycle", Desalination and Water Treatment, vol. 54, no. 2, pp. 305-315, 2014, https://doi.org/10.1080/19443994.2014.880157

[12] M. Esen and T. Yuksel, "Experimental evaluation of using various renewable energy sources for heating a greenhouse", Energy and Buildings, vol. 65, pp. 340-351, 2013, https://doi.org/10.1016/j.enbuild.2013.06.018

A. Kabeel and E. El-Said, "A hybrid solar desalination system of air humidification, dehumidification and water flashing evaporation: Part II. Experimental investigation", Desalination, vol. 341, pp. 50-60, 2014, https://doi.org/10.1016/j.desal.2014.02.035

[14] J. Klausner, Y. Li, M. Darwish and R. Mei, "Innovative Diffusion Driven Desalination Process", Journal of Energy Resources Technology, vol. 126, no. 3, pp. 219-225, 2004, https://doi.org/10.1115/1.1786927

[15] Klausner, Y. Li and R. Mei, "Evaporative heat and mass transfer for the diffusion driven desalination process", Heat and Mass Transfer, vol. 42, no. 6, pp. 528-536, 2005, https://doi.org/10.1007/s00231-005-0649-2

[16] F. Alnaimat, J. Klausner and R. Mei, "Transient analysis of direct contact evaporation and condensation within packed beds", International Journal of Heat and Mass Transfer, vol. 54, no. 15-16, pp. 3381-3393, 2011. https://doi.org/10.1016/j.ijheatmasstransfer.2011. $\underline{03.048}$

[17] A. Eslamimanesh and M. Hatamipour, "Mathematical modeling of a direct contact humidification-dehumidification desalination process", Desalination, vol. 237, no. 1-3, pp. 296304, 2009, https://doi.org/10.1016/j.desal.2008.01.023

[18] M. Zamen, M. Amidpour and M. Firoozjaei, "A novel integrated system for fresh water production in greenhouse: Dynamic simulation", Desalination, vol. 322, pp. 52-59, 2013, https://doi.org/10.1016/j.desal.2013.04.024

[19] N. Shekarchi and F. Shahnia, "A comprehensive review of solar-driven desalination technologies for off-grid greenhouses", International Journal of Energy Research, vol. 43, no. 4, pp. 1357-1386, 2018, https://doi.org/10.1002/er.4268

[20] Yin, J., et al., Correlation between Urban Morphology and Wind Environment in Digital City using GIS and CFD Simulations. International Journal of Online Engineering, vol. 10, no. 3, 2014, https://doi.org/10.3991/ijoe.v10i3.3631

\section{Authors}

Vasyl Savchenko, Ph.D., assistant professor Head of Department Department of Machine operation and Service of Technological Systems Polissya National University Staryy Bulvar, 7, Zhytomyr, Zhytomyr region, 10002, received the Master degree in Agricultural engineering from the Zhytomyr State Agroecological University (ZHNAEU), Zhytomyr, Uktaine, in 2001 and the Ph.D. degree in the specialty of Machinery and means of agricultural production'smechanization of agricultural production from the Kirovograd National Technical University (KNTU), Kirovograd, Ukraine, in 2009. Since 2009 until 2019, he has been a Associate professor of the National Agroecological University of Ukraine. Since 2019 - 
Associate professor of the Polissia National University ,Zhytomyr, Ukraine. His current research interests includethe reliability of technological systems, engineering of technological processes in the conditions of the protected soil, engineering ecology and service of technological systems, modern technologies of plants cultivation in industrial greenhouses. Email: (dgs-ua@ukr.net) Ukraine ORCID ID: 0000-00020921-1424.

Kravtsov Andrii, Ph.D., assistant professor Faculty of Technological Systems and Logistics Kharkiv Petro Vasylenko National Technical University of Agriculture Kharkiv, Alchevskih street 44, Ukraine, received the Master degree in agricultural machinery and equipment from Kharkiv Petro Vasylenko National Technical University of Agriculture (KhNTUSG), Kharkiv, Ukraine, in 2007 and the the Ph.D. degree in "Friction and wear in machines" Kharkiv Petro Vasylenko National Technical University of Agriculture (KhNTUSG), Kharkiv, Ukraine, in 2013. From 2014 to 2018 he worked as an associate professor of the Department of Transport Technologies and Logistics of Kharkiv Petro Vasylenko National Technical University of Agriculture. Since 2018 - Dean of the Faculty of Technological Systems and Logistics of Kharkiv Petro Vasylenko National Technical University of Agriculture, Ukraine. His current research interests include the problems of friction and wear in machines, the use of fuels and lubricants, the reliability of tribotechnical systems, agrologistics, transport and warehousing logistics. Email:kravcov_84@ukr. ne. ORCID ID: 0000-0003-3103-6594.

Minenko Serhii, Ph.D, assistant professor Department of Machine operation and Service of Technological Systems Polissya National University Staryy Bulvar, 7, Zhytomyr, Zhytomyr region, 10002, Ukraine, received the Master degree in Agriculturalengineering from the Zhytomyr State Agroecological University (ZHDAEU), Zhytomyr, Ukraine, in 2005 and the Ph.D. degree in the specialty of Machinery and means of agricultural production's mechanization of agricultural production from the Kirovograd National Technical University (KNTU), Kirovograd, Ukraine, in 2011. Since 2011 until 2019, he has been aAssociate professor of the National Agroecological University of Ukraine.Since 2019 -assistant professor Department of Machine operation and Service of Technological System of the Polissia National University, Zhytomyr, Ukraine. His current research interests includethe reliability of technological systems, engineering of technological processes in the conditions of the protected soil, service of technological systems, modern technologies of plants cultivation in industrial greenhouses. Email: (dgs-ua1@ukr.net) ORCID ID: 0000-0003-0327-0017

Kulykivskiy Volodymyr, Ph.D., assistant professor Department of Machine operation and Service of Technological Systems Polissya National University Staryy Bulvar, 7, Zhytomyr, Zhytomyr region, 10002, Ukraine, received the Master degree in Agriculturalengineering from the Zhytomyr State Agroecological University (ZHNAEU), Zhytomyr, Ukraine, in 2006 and the Ph.D. degree in the specialty of Machinery and means of agricultural production's mechanization of agricultural production from the Vinnytsia National Agrarian University (VNAU), Vinnytsia, Ukraine, in 2012. Since 2012 until 2019, he has been aAssociate professor of the National AgroecologicalUniversity of Ukraine.Since 2019 -assistant professor 
Department of Machine operation and Service of Technological System of the Polissia National University,Zhytomyr, Ukraine.His current research interests includethe reliability of technological systems, operation of machines and technological equipment in agriculture. Email: (kylikovskiyv@ukr.net). ORCID ID: 0000-0003-0327-0017.

Savchenko Liudmyla, Ph.D., Associate Professor Department of Electrification, automation of production and engineering ecology Polissya National University, Ukraine, received Ph.D. degree in the specialty of History of science and technology from the National Agricultural Library of the National Academy of Agrarian Sciences of Ukraine, Kyiv, Ukraine, in 2015. Since 2015 until 2019, he has been aAssociate professor of the National AgroecologicalUniversity of Ukraine. Since 2019 Associate Professor Department of Electrification, automation of production and engineering ecology Polissya National Universit,Zhytomyr, Ukraine. Her current research interests include the engineering of technological processes, engineering ecology,automation of production and occupational health in. Email: (slgua@ukr.net). ORCID ID: 0000-0002-7689-4982

Article submitted 2021-05-10. Resubmitted 2021-06-09. Final acceptance 2021-06-09. Final version published as submitted by the authors. 